https://doi.org/10.52058/2786-5274-2021-2(2)-101-115

Кудлай Ірина Володимирівна старший викладач кафедри «Міжнародних відносин та права», Державний університет «Одеська політехніка», пр. Шевченко, 1, м. Одеса, 65044, тел.: (050) 175-71-56, e-mail: kiv@op.edu.ua, https://orcid.org/0000-0002-6154-5245

Бабіна Валентина Олександрівна кандидат політичних наук, доцент кафедри «Міжнародних відносин та права», Державний університет «Одеська політехніка», пр. Шевченко, 1, м. Одеса, 65044, тел.: (067) 716-73-05, e-mail: ona2009@ukr.net, https://orcid.org/0000-0003-2796-5024

Моісесва Тетяна Миколаївна кандидат історичних наук, доцент каф. «Міжнародних відносин та права», Державний університет «Одеська політехніка», пр. Шевченко, 1, м. Одеса, 65044, тел.: (067) 9514452, e-mail: m.tatyana.n.33@gmail.com, https://orcid.org/0000-0001-7129-6046

\title{
ПРОБЛЕМИ СДНОСТІ ПРОФЕСІОНАЛІЗМУ ТА КУЛЬТУРИ В КОМУНІКАТИВНИХ ВІДНОСИНАХ ЕПОХИ ГЛОБАЛІЗАЦІЇ
}

Анотація. Сьогодні міжнародні зв'язки об'єднують компанії практично у всіх країнах світу. I у кожної держави своя політична ситуація, своя історія, свої традиції, своя культура; у кожної компанії, в свою чергу, свій статут і свої вимоги до партнерів і персоналу. Все це викликає серйозні ускладнення і труднощі для розвитку міжнародних зв'язків.

Основною метою крос-культурного спілкування є вивчення та використання поведінкових закономірностей, властивих різним національним соціальним і діловим колам. Знання національних культурних особливостей сприятиме подоланню міжкультурних бар'єрів, встановлення ефективних комунікацій i взаєморозуміння між представниками різних культур. Міжкультурна, кроскультурна, міжнародна комунікація в сучасний час глобалізації стає дуже важливою ланкою у вивченні впливу культури на вербальну мову і невербальну поведінку, гендерні відмінності, на соціальну поведінку та діяльність організації.

Крос-культурна комунікація являє собою складне і багатоаспектне явище, в той же час, це процес зі своїми властивостями, внутрішніми закономірностями $і$ суперечностями. Саме тому в наш час вона $\epsilon$ предметом комплексних наукових досліджень. Безумовно, крос-культурна комунікація як такова існувала 3 найдавніших часів, проте саме в XXI ст. остаточно усвідомлена необхідність їі не тільки практичного, а й наукового, теоретико-методологічного вивчення та 
рефлексії.

У даній статті аналізується вплив крос культурної комунікації на поведінку співробітників у представництвах усього світу, звертається увага на ведення міжнародних переговорів, вирішення конфліктних ситуацій, коли дипломати $\epsilon$ представниками різних культур. Розглядаються питання особливостей поведінки персоналу організацій, обумовлених культурними відмінностями; формування поведінкових навичок, необхідних для соціальної і професійної адаптації в умовах різних культур; формування знань про необхідність врахування культурних особливостей працівників організації при побудові систем комунікації і веління дипломатичних переговорів.

Ключові слова: культура, крос-культурна адаптація, крос-культурна комунікація, міжнародні переговори, переговорний процес, мультикультурна среда, міжнародне співробітництво, культурні відмінності, конфлікт, вербальна i невербальна комунікація, дипломатичний протокол, дипломатичний етикет. міжкультурна комунікація, теорія міжкультурної комунікації, мова, культурна компетенція, взаємодія культур.

Kudlai Iryna Volodymyrivna Senior lecturer of the department "International Relations and Law", State University "Odessa Polytechnic", Shevchenko Ave., 1, Odessa, 65044, tel.: (050) 175-71-56, e-mail: kiv@op.edu.ua, https:// orcid.org/0000-0002-6154-5245

Babina Valentyna Oleksandrivna Candidate of Political Science, Associate Professor of the Department "International Relations and Law", State University "Odessa Polytechnic", Shevchenko Ave., 1, Odessa, 65044, tel.: (067) 716-73-05, e-mail: ona2009@ukr.net, https://orcid.org/0000-0003-2796-5024

Moiseeva Tetyana Mykolayivna Candidate of Historical Sciences, Associate Professor of the department "International Relations and Law", State University "Odessa Polytechnic", Shevchenko Ave., 1, Odessa, 65044, tel.: (067) 951-44-52, e-mail: m.tatyana.n.33@gmail.com, https://orcid.org/0000-0001-7129-6046

\section{PROBLEMS OF THE UNITY OF PROFESSIONALISM AND CULTURE IN COMMUNICATIVE RELATIONS IN THE AGE OF GLOBALIZATION}

Abstract. Today, international relations unite companies in almost all countries of the world. And each state has its own political situation, its own history, its own traditions, its own culture; each company, in turn, has its own charter and its own requirements for partners and staff. All this causes serious complications and difficulties for the development of international relations. 
The main purpose of cross-cultural communication is to study and use the behavioral patterns inherent in different national social and business circles. Knowledge of national cultural features will help to overcome intercultural barriers, establish effective communication and mutual understanding between representatives of different cultures. Intercultural, cross-cultural, international communication in today's globalization is becoming a very important link in the study of the impact of culture on verbal language and nonverbal behavior, gender differences, social behavior and activities of the organization.

Cross-cultural communication is a complex and multifaceted phenomenon, at the same time, it is a process with its own properties, internal patterns and contradictions. That is why in our time it is the subject of comprehensive research. Of course, crosscultural communication as such has existed since ancient times, but it is in the XXI century. the necessity of its not only practical, but also scientific, theoretical and methodological study and reflection is finally realized.

This article analyzes the impact of cross-cultural communication on the behavior of employees in missions around the world, draws attention to international negotiations, conflict resolution, when diplomats are from different cultures. The questions of features of behavior of the personnel of the organizations caused by cultural differences are considered; formation of behavioral skills necessary for social and professional adaptation in different cultures; formation of knowledge about the need to take into account the cultural characteristics of employees of the organization in the construction of communication systems and the command of diplomatic negotiations.

Keywords: culture, cross-cultural adaptation, cross-cultural communication, international negotiations, negotiation process, multicultural environment, international cooperation, cultural differences, conflict, verbal and nonverbal communication, diplomatic protocol, diplomatic etiquette. intercultural communication, theory of intercultural communication, language, cultural competence, interaction of cultures.

Постановка проблеми. Відмінними рисами кінця XX початку XXI століття є інтернаціоналізація та глобалізація. Свропейський вектор України в політичній, економічний, соціальній сферах нашого життя формує чітку спрямованість всіх верств населення на переосмислення майбутнього. У зв'язку 3 цим необхідно звернути увагу на те, що успішна професійна діяльність фахівців будь-якої сфери, а особливо міжнародників, дипломатів і журналістів в значній мірі залежить не тільки від володіння ними спеціальними професійними знаннями і знаннями іноземних мов, а й від знання мовного етикету, особливостей культури країни, 3 представниками якої налагоджуються ділові відносини, національних стилів спілкування, основ міжнародного етикету. У міжнародне співробітництво включаються носії різних культур, з'являється велика кількість мовних контактів, прискорюються темпи спілкування і комунікації. Таким чином, стилі спілкування 
безпосередньо пов'язані з культурою. Якщо в культурі спостерігається великий розрив, можна очікувати, що у функціях комунікації будуть спостерігатися значні проблеми.

Сьогодні міжнародні зв'язки об'єднують компанії практично у всіх країнах світу. І у кожної держави своя політична ситуація, своя історія, свої традиції, своя культура; у кожної компанії, в свою чергу, свій статут і свої вимоги до партнерів і персоналу. Тому освоювати простір світового ринку без знання іноземних мов і ділового етикету неможливо. Все це викликає серйозні ускладнення і труднощі для розвитку міжнародних зв'язків.

Міжнародні контакти України з зарубіжними державами також отримують все більший розвиток. Вони охоплюють весь спектр міждержавних відносин: політичні, економічні, гуманітарні, військово - і науково-технічні, консульські та інші. Щорічно в нашій країні приймають сотні іноземних делегацій на рівні глав держав, урядів, міністрів закордонних справ, міністерств і відомств, представників міжнародних організацій і ділових кіл. I навпаки - представники нашої країни здійснюють активні візити за кордон.

Під крос-культурними комунікаціями розуміється спілкування і взаємодія людей - представників різних культур.

Актуальність обраної теми обумовлена розширенням міжнародних зв'язків, і як наслідок, розвитком міжнаціонального спілкування. У сучасних умовах глобалізації, коли розвиток всесвітньої інтеграції торкнувся всі сфери діяльності, міжнародні контакти стають все більш тісними, а практика міжнародних переговорів стає все більш інтенсивною. У зв'язку з цим не можна недооцінювати роль крос-культурних аспектів.

Таким чином, поява нових компаній і активне залучення їх до бізнесу, що діють на міжнародному ринку компаній, необхідність переговорних процесів, для вирішення питань бізнесу і політики, врегулювання конфліктів - все це актуалізує проблематику вивчення національних стилів ведення переговорів, вимагає знань культурних особливостей інших країн, так як від них залежить ефективність переговорного процесу.

У даній статті аналізується вплив крос культурної комунікації на поведінку співробітників у представництвах усього світу, звертається увага на ведення міжнародних переговорів, вирішення конфліктних ситуацій, коли дипломати є представниками різних культур.

Аналіз останніх досліджень i публікацій. Явища крос-культурної комунікації складають великий інтерес для багатьох сфер i наук. Аналіз сутності крос-культурної комунікації викладені в роботах зарубіжних і вітчизняних вчених (М. Бубера, М. Вебера, Х.-Г. Гадамера, Е. Гуссерль, Ф. Джандта, К. Клакхона, А. Л. Кребера, Г. Кріплення , К. Леві-Стросса, Дж. Мердока, Р. Мертона, Т. Парсонса, А. Радкліффбрауна, Ф. Розенцвейга, У. Самнера, Л. Уайта, Ч. Філмора, Л. Фрейя, П. Фрейдмана, М. Хайдеггера, Ф. Ебнера, Н. Д. Арутюнова, Ю. В. Арутюнян, Д. Б. Гудкова, 
А. Г. Здравозадумова, В. Г. Зінченко, І. А. Ільяєва, Ю. Н. Караулова, А. А. Леонтовича, Ю. М. Лотмана, В. В. Петрова, В. Д. Попкова, А. П. Садохина, А. В. Соколова, С. Г. Тер-Минасова, Л. В. Щерба, Л. Якубинского та ін.). Поняття "міжкультурна (крос-культурна, міжетнічна) комунікація" (або «міжкультурна інтеракція») з'явилося завдяки американським вченим Г. Трейгера і Е. Холу, які в роботі «Культура i комунікація. Модель аналізу» (1954) досліджували крос-культурну комунікацію як одну 3 галузей людської діяльності. Вони розглядали iï як головний інструмент адаптації людини до навколишнього світу. Подальша розробка теоретичних основ міжкультурних комунікацій продовжена Дж. Кондоном і I. Фаті в роботі "Вступ до міжкультурної комунікації". У другій половині XX століття крос-культурні дослідження стали здійснюватися в найрізноманітніших сферах науки.

Дослідженням комунікативної компетентності займалися також: T. Бутенко, I. Данченко, Н. Завініченко, А. Касаткіна, I. Козубовська, А. Краєвська, С. Макаренко, В. Назаренко, Н. Тимофєєва, А. Хом'як, В. Черевко та ін.. Л. Г. Почебут приділяла велику увагу цим питанням, розробила теорію міжкультурної комунікативної компетентності як психологічної передумови конструктивної взаємодії представників різних культур.

Серед класичних робіт зарубіжних досліджень комунікативної компетентності з точки зору теорії комунікації і культурології слід відзначити праці: L. Bachman, M. Canale, N. Chomsky, K. Foss, O. Argie, J.Koester, D. O'Hair, A. Palmer, G. Rickheit, H. Widdowson, C. Sabee і ін. Також в західній літературі дуже ретельно ці питання вивчали такі вчені, як Г. Хофстед, Ф. Тромпенаарс, С. Ронен, Р. Мід, Е. Шейн, М . Портер, Ф. Лютенс.

Якщо говорити про переговорний процес, про його роль, значення і вплив традиційного національного стилю, то необхідно звернути увагу на праці лорда Актона, Е. Ренана, О. Бауера, Г. Лебона.

Разом 3 тим, проблема формування комунікативної компетентності i сьогодні залишається актуальною, оскільки ii підвищення в усіх сферах життєдіяльності в кінцевому результаті означає: раціоналізацію механізмів управління суспільством; затвердження діалогу в якості пріоритетної форми спілкування, як єдиного способу вирішення глобальних проблем «цивілізаційних викликів»; культуру ведення професійних і міжнародних переговорів у всіх сферах; формування моральної, духовної особистості шляхом розширення рівня відповідальності та свободи, в яких особистість шукає свої життєві смисли.

У той же час, слід підкреслити, що ми підтримуємо думку багатьох зарубіжних вчених (Д. Робінсон, М. Мескон та ін.), які вважають, що неефективне спілкування часто $є$ однією 3 істотних перешкод на шляху 
досягнення позитивного результату в професійній діяльності, а іноді стає причиною виникнення проблем в професійній сфері.

Мета статті - обгрунтувати важливість розвитку комунікативних навичок ведення переговорів, дослідити сучасний вплив крос-культурної компетентності на особливості комунікації при веденні міжнародних переговорів і спрогнозувати подальші шляхи їі розвитку.

Виклад основного матеріалу. Ділове спілкування в міжнародному аспекті є складним процесом, опосередкованим ціннісною несумісністю національних бізнес-культур. Воно повинно відбуватися так, щоб виключити будь-який міжнародний конфлікт, викликаний зіткненням різних уявлень про належну поведінку. Цьому сприяє знання i дотримання вимог i правил культури міжнародного спілкування (крос-культурної комунікації) [1].

Крос-культурна комунікація - це вербальна i невербальна взаємодія представників різних моральних систем, світоглядів, релігій і таке інше.

У сучасному глобальному світі все більшої актуальності набуває питання про взаємовплив і взаємопроникнення різних культур. Культурні досягнення різних народів стають надбанням всіх. Створюються транснаціональні корпорації, що об'єднують в трудовому процесі представників різних народів i культур, дедалі потужнішими стають потоки міграції (природні, примусові та бізнес міграції). Середовище, в якому живе і здійснює свою діяльність людина, стає поліетнічним. Сьогодні в умовах інтернаціоналізації бізнесу і економіки, вивчення культурної самобутності, поведінкових характеристик, ієрархії цінностей, особливостей світогляду представників різних культур є надзвичайно актуальним.

Культура в сьогоднішньому контексті відрізняється від традиційного, більш своєрідного визначення, що використовується, зокрема, в західних мовах, де це слово часто має на увазі вишуканість.

Також необхідно визначитися, що ж таке комунікативна компетентність.

Здатність людини адекватно відповідати на різноманітні проблемні ситуації, 3 якими він стикається в процесі спілкування 3 іншими людьми, це і $\epsilon$ комунікативна компетентність.

Міжкультурна комунікативна компетентність виражається в позитивному ставленні, толерантності та довірі, знанні принципів і правил міжкультурної комунікації, вміння розуміти і взаємодіяти з представниками різних культур.

Формування міжкультурної комунікативної компетентності передбачає отримання знань про свою та інших культурах (мову, історію, мистецтво, літературу, архітектуру, міфології і фольклорі, релігії та ін.). Однак знань про культурні особливості недостатньо, необхідно також розвиток умінь, навичок, специфічної здатності до спілкування з представниками інших народів і культур.

До числа найбільш ефективних принципів крос культурної взаємодії ми відносимо: інформованість про культуру ділового партнера, готовність вступити в діалог, встановлення відносин довіри і взаємоповаги, навички розуміння та 
інтерпретації інших культур, прийняття дівергентності та рівнозначності ділових культур.

Культура ж - це переконання, цінності, спосіб мислення і звичаї певної спільності людей. Вона включає в себе модель поведінки і норми цієї спільності правила, припущення, сприйняття, а також логіку і міркування, характерні для даної групи. По суті, кожен з нас вихований в системі переконань, яка настільки сильно впливає на наші індивідуальні погляди, що ми не завжди можемо пояснити або навіть зрозуміти ії вплив. Ми схожі на інших представників нашої культури, і тому ми прийняли рішення і прийшли до спільної думки про те, що доречно, а що недоречно. По суті, все, що ми робимо, було сформовано культурою, в якій ми виросли. Саме культура особистості включає в себе самі різні речі - як ми їмо, граємо, одягаємося, працюємо, думаємо, взаємодіємо і спілкуємося. Точно так же чоловік, перебуваючи в іншій країні повинен визначатися ऑï культурними впливами, вивчити традиції, манери і стилі поведінки, властиві даній країні. Ці культурні особливості впливають на те, як ми думаємо і спілкуємося.

3 розвитком суспільства змінюються і цінності, глобалізація і конвергенція нових технологій i комунікаційних структур сприяють формуванню більш широкої міжнародної споживчої культури і цінностей.

Цінність є не властивістю будь-якої речі, а сутністю і одночасно умовою повноцінного буття об'єкта. Цінності визначають зсередини, 3 глибин індивідуального та соціального життя те, що ми називаємо культурою народу i суспільства. На думку Г. П. Вижлецова [4], культура зберігає єдність нації, держави і суспільства, оскільки вона визначається ступенем здійснення цінностей та їх реалізацією у всіх сферах людської життєдіяльності. Через це культура кожної країни є первинною до іiї економіці, політиці, праву і моралі [2].

Процеси глобалізації також неминуче призводять до деякого розмивання національних кордонів, що сприяє не тільки міжнаціональної міграції трудових ресурсів, а й активному проникненню на національні території нових поглядів, ідей, культур. Відмінності між різними культурними групами або підгрупами, навіть якщо вони говорять однією мовою, можуть створити проблеми і значно ускладнити розуміння один одного.

Первісне формування культурних констант, безумовно, визначалося географічними і природно-кліматичними характеристиками районів компактного проживання національних спільнот, і ці особливості зберігають своє важливе значення навіть сьогодні: національні характеристики представників Півдня i Півночі, особливості поведінки населення Сходу або Заходу. Але під впливом політичних, економічних, релігійних, соціальних та інших процесів історичного розвитку окремих націй, становлення i еволюції національних держав, ці культурні константи істотно змінювалися. На цю динаміку, в свою чергу, впливали результати міжнаціональної взаємодії: відбувалося взаємопроникнення 
культур, особливо тих націй, які проживають в одному регіоні [3].

Кожній національній культурі відповідає певна, тільки їй притаманна система цінностей. Кожне нове покоління, переймає цінності і переконання попереднього, відтворює культурну спадщину своєї країни. При цьому передаються не тільки поведінкові стереотипи, а й способи і моделі управління, що відрізняють одну країну від іншої. Саме за цими ознаками можна визначити ту чи іншу модель ділової культури країни [1].

У міру того як глобалізація зблизила світ, ділові відносини між представниками різних культур відбуваються щодня. Одним 3 проявів навичок міжкультурного спілкування сьогодні виступає політика культурної дипломатії. Адже вона володіє неабияким спектром можливостей впливати на питання безпеки, формування міжнародного іміджу, успішного ведення переговорів, стимулювання розвитку культури i економіки, зміцнення національної ідентичності, просування системи демократичних цінностей тощо.

У той же час, культурна дипломатія як політика не повинна обмежуватися завданнями виключно сфери зовнішньополітичних відносин. Оперативно реагуючи на культурні запити суспільства, вона бере участь в його формуванні, осмисленні власного досвіду i плануванні майбутнього. Власне, культурна дипломатія може і повинна бути складовою культурної політики держави, але тільки в тому випадку, якщо та відповідає актуальним потребам соціуму.

Не існує двох національностей, які б бачили світ однаково. У зв'язку з цим необхідно звернути увагу, що крос культурна комунікація в найширшому сенсі відноситься до того, як і чому ми так думаємо і діємо.

Велика частина проблем в будь-якої міжкультурної взаємодії виникає 3 наших очікувань. Проблема в тому, що кожного разу, коли ми маємо справу 3 людьми 3 іншої культури - будь то в нашій країні або в усьому світі, - ми очікуємо, що люди будуть вести себе так само, як ми, і за тими ж правилами.

Поінформованість про культуру іншої держави найчастіше означає розуміння цінностей і поглядів іншої культури. Наші культурні орієнтири, сформовані нашою освітою, релігією або соціальною структурою, також критично впливають на ділові взаємодії. Вивчаючи культури, дуже важливо пам'ятати, що все культури постійно розвиваються.

Залежно від фактору часу бізнес-культури поділяються на: монохромні та поліхромні. Представники перших дуже цінують час (як власне, так і ділових партнерів), вони дуже пунктуальні, вимогливі до ділових зустрічей і дотримання їх порядку денного. Поліхромні бізнес-культури більш гнучкі. Їх представники не надають занадто великого значення фактору часу, пунктуальності. Ділові зустрічі менш формальні, ніж в першому випадку. Під час цих зустрічей можуть обговорюватися і питання, які заздалегідь не були внесені до порядку денного.

У міжкультурному спілкуванні є певні відмінності щодо межі допустимої емоційності. Якщо для експресивної культури ділових відносин характерною $є$ підвищена емоційність (регіони Середземномор'я, Південна Америка, частково 
США, Канада, Австралія, Східна Свропа, Африка), то стримана культура ділових відносин передбачає раціональні способи взаємодії (країни Східної та Південної Азії, Північна Свропа, Німеччина, Великобританія, Японія).

Слід зазначити, що представники експресивних (контактних) культур не звертають уваги на особистий простір партнера по спілкуванню i часто порушують його, що не характерно для стриманих (дистантних) культур. У експресивних культурах ділових відносин партнери можуть дозволити собі переривати монолог партнера, що в стриманих культурах неприпустимо.

В системі крос-культурного спілкування існує також індивідуалістична i колективістська культури. Перша 3 них грунтується на принципах автономіі особистості, поваги їі прав і свобод, друга - спрямована на збереження, постійне відтворення національних звичаїв, традицій, норм.

Представники західноєвропейських індивідуалістичних культур акцентують увагу на інформації, а не на способі іï донесення. Для них властива лаконічна мова, логічно розумне, послідовне, точне мислення. Носії колективістських культур (Схід, Азія) в спілкуванні звертають увагу на контекст повідомлення, тобто надають увагу не тільки тому, про що йде мова, але і тому, яким чином це висловлюється.

Результати здійсненого нами аналізу наукових джерел [2-6] свідчать, що в професійно-ділових стилях спілкування різних європейських країн $\epsilon$ істотні відмінності, які на сучасному етапі розширення міжнародних контактів i співробітництва в усіх сферах слід знати i враховувати, щоб досягти взаєморозуміння й успіху в спілкуванні. У міжнародному бізнесі виділяють арабську, азіатську і американську моделі комунікативної поведінки в бізнесі, які конкретизуються відповідними національними бізнесовими культурами i відрізняються як у вербальному, так і невербальному аспектах. Говорячи про європейську культуру ділового спілкування, то вона не є монолітною, а поєднує в собі різні типи комунікативної поведінки в бізнесі - формально-ієрархічні i егалітарні, максимально стримані i експресивні, монохромні i поліхромні культури спілкування, бізнес-культури, орієнтовані на угоду, і бізнес-культури, орієнтовані на відносини. Незважаючи на значні відмінності, всі європейські культури грунтуються на принципах автономії особистості, гідності людини, що відрізняє їх від колективістських культур арабо-азіатського світу.

Таким чином, це свідчить про те, що кожна група людей має свою унікальну культуру, тобто свій спосіб життя, цінності, переконання і образ мислення. Однак це не означає автоматичне прийняття, це просто означає розуміння світогляду іншої культури і того, як іiі історія, економіка і суспільство вплинули на те, що думають люди іншої держави. Розуміння, що дозволяє правильно інтерпретувати чиїсь слова і дії, означає, що ми можемо ефективно з ними взаємодіяти.

Конфуцій сказав наступне про культурні пересічних: «Люди зближуються один з одним по своїй загальній природі, але звички і звичаї поділяють їх». 
Переговори завжди були найважливішим інструментом дипломатії. Інституціалізація культурної дипломатії $\epsilon$ важливою умовою формування політики крос-культурної комунікації яка, 3 одного боку, буде впливати на питання національної безпеки і міжнародного іміджу, а 3 іншого - відкриє перспективи соціально-культурного та економічного розвитку держави, позитивно позначиться на внутрішній політичній стабільності, здатності бачити i планувати майбутнє. Однією з основних особливостей переговорів $є$ те, що їх учасники знаходяться в безпосередній взаємодії один з одним і у взаємній залежності.

Переговори через національні та культурні кордони створюють додаткові проблеми для їх учасників. Ще раз звернемо увагу на те, що всі ми - продукт культури і географічних регіонів, в яких ми виросли і живемо. Культура створює упередження в нашому сприйнятті, мотивації, інтересах і стратегіях, що може привести до безлічі конфліктів в процесі переговорів. Аспекти культури, які можуть вплинути на переговори, включають мову, діалект, соціальні норми, діловий етикет, релігію, цінності, кухню, гігієну, комфорт і особисті переваги. На міжнародні переговори також часто впливають історичні події, націоналізм, правові обмеження, тарифи, географічна віддаленість, топографічні умови, багатосторонні союзи і політичні конфлікти.

Якщо взяти до уваги той факт, що переговори з нашими співвітчизниками не $\epsilon$ легким завданням через багатьох індивідуальних відмінностей, було б розумно припустити, що переговори 3 іноземцями можуть бути ще важчими. Те, як ми сприймаємо і створюємо свою власну реальність, може повністю відрізнятися від способу мислення, поведінки і почуттів нашого двійника. На жаль, знання будьякої іноземної мови недостатньо, щоб, зіткнувшись з цією проблемою вирішити їі

Мова - це сукупність кодів, використовуваних в комунікації, які, якщо вони не використовуються ефективно, можуть виступати в якості бар'єру для встановлення розуміння і довіри. Різні нації і народності, як правило, мають своєрідний національний характер, який впливає на тип цілей i процесів, які суспільство ставить перед собою в переговорах. Ось чому уточнення і розуміння культурних відмінностей життєво важливо для успішної роботи в міжкультурної комунікації [24].

Необхідно звернути увагу, що навіть погляд на переговори може відрізнятися в різних культурах. Наприклад, в західних культурах переговори розглядаються як бізнес, а не як соціальна діяльність, але в інших культурах першим кроком в переговорах є встановлення довірчих відносин. Також важливо пам'ятати, що означає згоду в різних культурах. Наприклад, в Китаї кивок голови не означає, що китайський партнер погоджується 3 тим, що ви пропонуєте, а просто те, що вони слухають і стежать за тим, що ви говорите.

Взагалі, вміння ефективно вести переговори - складна річ, яка вимагає певних навичок: необхідно знати, як проводити переговори, слідуючи яким алгоритмам, як уникнути помилок, володіння умінням уважно слухати, 
намагатися зрозуміти аргументи опонента. Правильно враховувати застосовувати знання і навички крос культурної комунікації - використовувати і розуміти міміку, жести, пози, інтонації, здатність до роботи відповідно до норм і традиціям інших країн. Також, одним 3 найбільш важливих навичок є вміння ставити питання, слухати і чути співрозмовника. Правильно поставлені запитання допомагають отримати 3 протилежного боку цінну інформацію, а також перевірити різні варіанти, які розглядалися під час підготовки до переговорів.

Досліджуючи питання дипломатичних переговорів, не можна ігнорувати технічний прогрес, наприклад так звану «віртуальну» дипломатію. Вона охоплює прийняття рішень, координацію, спілкування, яке здійснюється з використанням інформаційно-комунікаційних технологій. Цей вид дипломатії ефективно використовується Державним департаментом США i включає використання соціальних медіа, програмного забезпечення для Інтернет-телефонії, відеоканалів. При цьому віртуальна дипломатія не відмежовується від традиційних форм дипломатичних відносин і не $\epsilon$ їх заміною, а скоріше вагомим доповненням, яке може поліпшити i прискорити дипломатичні відносини, а також розширити їх сферу [14, с. 19].

Механізмом реалізації принципів міжнародного спілкування $\epsilon$ дипломатичний протокол, стандарти якого були закріплені Віденською конвенцією 1961 року. Серед безлічі визначень дипломатичного протоколу можна виділити наступне: "сукупність загальноприйнятих правил і традицій, яких дотримуються урядами, департаментами закордонних справ, дипломатичними представниками, службовцями та іншими посадовими особами в міжнародних відносинах". Це визначення є найбільш повним і відображає суть протокольної міжнародної діяльності. Згодом слово протокол стало вживатися для позначення дипломатичного етикету.

Протокольні практики поділяються на офіційні (державні, дипломатичні) i ділові. Державний протокол регулює відносини, що відбуваються на національному рівні, сферами дипломатичного протоколу $\epsilon$ міжнародні відносини. Чимало важливою складовою в здійсненні міжнародного співробітництва є ділова етика. В цілому підтверджено, що брак знань в сфері ділового етикету впливає на репутацію компаній i негативно позначається на фінансових результатах. При цьому, найчастіше помилки в діловому етикеті здійснюють китайці (67 \%), за якими слідують італійці (65\%), американці (58\%), німці (56\%) та іспанці (52\%) [11].

Таким чином, для підтримки ефективної взаємодії на високому рівні використовуються навички ведення дипломатичного протоколу та етикету. Вивчивши міжнародні правила ввічливості, формальні норми спілкування i церемоніальні звичаї, яким слід дотримуватися на офіційних заходах, ми отримуємо практичне уявлення про тонких взаємодіях, які поліпшать якість ведення переговорів в самих різних умовах.

3 огляду на міжнародну обстановку в світі і, зокрема, в Україні, необхідно 
звернути увагу на те, що частиною життя є конфлікти і вони можуть виникнути в будь-який момент. Для дипломатів і державних діячів, переговори - це також шлях від конфлікту до врегулювання конфлікту, спосіб мирного вирішення виниклих конфліктних протиріч і врегулювання конфліктів шляхом взаємодії сторін 3 метою знаходження взаємоприйнятних рішень і письмового оформлення досягнутих угод, можливість об'єднати розходяться інтереси в загальне рішення в інтересах усіх залучених сторін. Це, звичайно, ідеальний підхід до переговорного процесу, i необхідно вміти регулювати перешкоди i обмеження, які часто підривають ефективність переговорного процесу, змінюючи хід переговорного процесу на шкоду залученим сторонам.

Висновки: Отже, результати аналізу нашого дослідження дозволяють зробити наступні висновки:

культурна дипломатія як інструмент «м'якої сили» визнається все більш актуальним напрямком державної політики в зв'язку з необхідністю оперативно вирішувати питання національної безпеки, позитивного міжнародного іміджу, налагодження глобальних комунікацій. У кожній країні свої правила ведення переговорів. Перед переговорами за кордоном необхідно вивчити норми цієї культури. Нерозуміння культури людини або групи людей, 3 якими ви ведете переговори, може бути серйозною помилкою.

Таким чином, необхідно чітко розуміти концепцію культурних виразів, які можуть бути зрозумілі тільки людиною, що належить до певної культури. У кроскультурної комунікації неможливо досягти реального успіху без дотримання культурних норм і традицій кожної країни в процесі спілкування, при проведенні міжнародних переговорів необхідно враховувати крос-культурні особливості країн. Підготовка до переговорів з іноземними партнерами збільшує ефективність переговорного процесу і знижує ризики непорозуміння і зриву угоди. Партнери повинні розуміти культурні особливості інших, щоб краще орієнтуватися в тому, що в іншому випадку могло б перетворитися в безладну ситуацію.

\section{Лimepamypa:}

1. Богдан С. К. Мовний етикет українців: традиції і сучасність. К., 1998.

2. Ведение переговоров. Стратегии и тактики: учебное пособие / Под ред. М. Г. Власовой. СПбГУ, 2012. 217 с.

3. Выжлецов Г. П. Креативность культуры: ценность и отчуждение. «Теория культуры», СПбГУ, 2014. с. 82-93.

4. Данилюк І. В. Мовні конфлікти та конструювання етнічної і національної ідентичності // Соціальна психологія. Київ, 2005. Вип. 3 (11). С. 43-51.

5. Индина Т. А. Особенности международного делового этикета // СЕО 2.0. 2016.

6. Козловська Г. В. Актуальність проблем міжкультурної комунікації в сучасних умовах. Київ. : 2005. 176 с.

7. Льюис Р. Д. Ділові культури в міжнародному бізнесі. Від зіткнення до взаєморозуміння. М.: Справа, 2001. 
8. М'язова І. Ю. Особливості тлумачення поняття «міжкультурна комунікація». // Філософські проблеми гуманітарних наук. 2006. № 8. С. 108-113.

9. Манакін В. М. Мова і міжкультурна комунікація. К.: Академія, 2012. 281 с.

10. Мясоєдов С. П. Основи кроскультурного менеджменту. М: Справа, 2003. С. 186-210 Названы главное ошибки в деловом этикете. Исследование компании Booking.com. [Сайт] URL: http://style.rbc.ru/guide/travel/571637f79a79472acdb345af (дата обращения 20.04.2021).

11. Ниренберг Д. Маестро переговорів. Діловий бестселер. Мінськ: Парадокс, 1996.

12. Персикова Т. Н. Межкультурная коммуникация и корпоративная культура. М. 2004.

13. Пожуєв В. І. Інформаційно-комунікативні технології як один 3 найважливіших факторів формування суспільства // Гуманітарний вісник Запорізької державної інженерної академії: [зб. наук. пр.]. Запоріжжя: Вид-во ЗДІА, 2012. Вип. 49 . С. 5-16.

14. Почепцов Г. Г. Теорія комунікації. 2-ге вид., доп. / Г. Г. Почепцов К., 1999. 307 с.

15. Самохина Т. С. Эффективное деловое общение в контекстах разных культур и обстоятельств. М. 2005.

16. Спэнгл М. Решение проблем в разном контексте / пер. с анл. / М. Спэнгл. Х. : Гуманитарный Центр, 2009. 592 с.

17. Столкновение культур: Путеводитель для всех, кто делает бизнес за границей: Учебное пособие / Под ред. Р. Льюис. М.: Манн, Иванов и Фербер, 2013. 640 с.

18. Тер-Минасова С. Г. Мова й міжкультурна комунікація. М., 2000.

19. Хельд Д., Гольдблатт Д., Макгрю Э., Перратон Дж. Глобализация, культура и судьбы наций [Текст] / Д. Хельд, Д. Гольдблатт, Э. Макгрю, Жд. Перратон // Глобальные трансформации. Политика, экономика, культура; [пер. с англ. В. В. Сапова и др]. М.: Праксис, 2004. C. 386-441.

20. Четыре типа корпоративной культуры: Учебник / Под ред. Ф. Тромпеаарс, Ч. Х. Тернер. Пер. с англ. Минск: Поппури, 2012. 488 с.

21. Хол Дж. Фаст. Э. Як зрозуміти іноземця без слів. Мова тіла. М.: Вече, 1995. 432 с.

22. Яцимірська Марія Моделі міжкультурної персвазії в Інтернеті // Сучасна медіа культура: контент, концепції, перспективи (українсько-польський досвід) / монографія: [Й. Лось, С. Гавронський, Т. Лильо, М. Уліта та ін.]. Львів : ЛНУ імені Івана Франка, 2012. C. $280-294$

23. Яшенкова О. В. Основи теорії мовної комунікації : навч. посіб. / О. В. Яшенкова. К : ВЦ «Академія», 2010. $312 \mathrm{c.}$

24. Camille Passler Schuster, Michael J Copeland Cross-cultural communication: Issues and implications // International business negotiations, 1996. p. 131-152.

25. Camille Passler Schuster, Michael J Copeland Cultural theory in use: the intersection of structure, process and communication in business practice Journal of Public Affairs: An International Journal 8 (4), 2008. 261-280.

\section{References:}

1. Bohdan S. K. Movnyy etyket ukrayintsiv: tradytsiyi i suchasnist'. [Language etiquette of Ukrainians: traditions and modernity]. K., 1998. [in Ukrainian].

2. Vedenye perehovorov. Stratehyy y taktyky [Negotiation. Strategies and tactics]: uchebnoe posobye (2012) / Pod red. M. H. Vlasovoy. SPbHU, 217 c. [in Russian].

3. Vyzhletsov H. P. (2014) Kreatyvnost' kul'tury: tsennost' y otchuzhdenye [Creativity of culture: value and alienation]. «Teoryya kul'tury», SPbHU, s. 82-93. [in Russian].

4. Danylyuk I. V. (2005) Movni konflikty ta konstruyuvannya etnichnoyi i natsional'noyi identychnosti [Language conflicts and the construction of ethnic and national identity] // Sotsial'na psykholohiya. Kyyiv, Vyp. 3 (11). S. 43-51. [in Ukrainian]. 
5. Yndyna T. A. (2016) Osobennosty mezhdunarodnoho delovoho étyketa [Features of international business etiquette] // CEO 2.0. [in Russian].

6. Kozlovs'ka H. V. (2005) Aktual'nist' problem mizhkul'turnoyi komunikatsiyi v suchasnykh umovakh. Кууілчясм [The urgency of the problems of intercultural communication in modern conditions]. $176 \mathrm{~s}$ [in Ukrainian].

7. L'yuys R. D. (2001) Dilovi kul'tury v mizhnarodnomu biznesi. Vid zitknennya do vzayemorozuminnya [Business cultures in international business. From confrontation to mutual understanding]. M.: Sprava, [in Ukrainian].

8. Manakin V. M. (2012) Mova i mizhkul'turna komunikatsiya. [Language and intercultural communication] K.: Akademiya, $281 \mathrm{~s}$. [in Ukrainian].

9. M"yazova I. YU. (2006) Osoblyvosti tlumachennya ponyattya «mizhkul'turna komunikatsiya» [Features of interpretation of the concept of "intercultural communication] // Filosofs'ki problemy humanitarnykh nauk. № 8. S. 108-113. [in Ukrainian].

10. Myasoyedov S. P. (2003) Osnovy kroskul'turnoho menedzhmentu. [Fundamentals of cross-cultural management]. M: Sprava, S. 186-210 Nazvany hlavnoe oshybky v delovom étykete. Yssledovanye kompanyy Booking.com. [Sayt] URL: http://style.rbc.ru/guide/travel/ 571637f79a79472acdb345af (data obrashchenyya 20.09.2021). [in Russian].

11. Nyrenberh D. (1996) Maéstro perehovoriv. Dilovyy best·seler. [Maestro of negotiations. Business bestseller]. Mins'k: Paradoks, 1996. [in Ukrainian].

12. Persykova T. N. (2004) Mezhkul'turnaya kommunykatsyya y korporatyvnaya kul'tura. [Persikova TN Intercultural communication and corporate culture]. M. [in Ukrainian].

13. Pozhuyev V. I. (2012) Informatsiyno-komunikatyvni tekhnolohiyi yak odyn z nayvazhlyvishykh faktoriv formuvannya suspil'stva [Pozhuyev VI Information and communication technologies as one of the most important factors in shaping societyxт] // Humanitarnyy visnyk Zaporiz'koyi derzhavnoyi inzhenernoyi akademiyi: [zb. nauk. pr.]. Zaporizhzhya: Vyd-vo ZDIA, 2012. Vyp. 49. S. 5-16. [in Ukrainian].

14. Pocheptsov H. H. (1999) Teoriya komunikatsiyi. [Theory of communication] 2-he vyd., dop. / H. H. Pocheptsov K. 307 s. [in Ukrainian].

15. Samokhyna T. S. (2005) Éffektyvnoe delovoe obshchenye v kontekstakh raznykh kul'tur y obstoyatel'stv. [Effective business communication in the contexts of different cultures and circumstances]. M. [in Russian].

16. Spénhl M. (2009) Reshenye problem v raznom kontekste [Problem solving in different contexts] / per. s anl. / M. Spénhl. KH. : Humanytarnyy Tsentr, 592 s. [in Russian].

17. Stolknovenye kul'tur: Putevodytel' dlya vsekh, kto delaet byznes za hranytsey: Uchebnoe posobye (2013) [Clash of Cultures: A Guide for Anyone Doing Business Abroad] / Pod red. R. L'yuys. M.: Mann, Yvanov y Ferber. 640 s. [in Russian].

18. Ter-Mynasova S. H. (2000) Mova y mizhkul'turna komunikatsiya. [Language and intercultural communication]. M. [in Ukrainian].

19. Khel'd D., Hol'dblatt D., Mak·hryu É., Perraton Dzh. (2004) Hlobalyzatsyya, kul'tura y sud'by natsyy [Tekst] [Globalization, culture and destinies of nations] / D. Khel'd, D. Hol'dblatt, É. Mak·hryu, Zhd. Perraton // Hlobal'nye transformatsyy. Polytyka, ékonomyka, kul'tura; [per. s anhl. V. V. Sapova y dr]. M.: Praksys. S. 386-441. [in Russian].

20. Chetyre typa korporatyvnoy kul'tury (2012): Uchebnyk [Four types of corporate culture] / Pod red. F. Trompeaars, CH. KH. Terner. Per. s anhl. Mynsk: Poppury. 488 c. [in Russian].

21. Khol Dzh. Fast. É. (1995) Yak zrozumity inozemtsya bez sliv. Mova tila. [How to understand a foreigner without words. Body language]. M.: Veche. 432 s. [in Ukrainian].

22. Yatsymirs'ka Mariya (2012) Modeli mizhkul'turnoyi persvaziyi v Interneti [Models of intercultural persuasion on the Internet] // Suchasna media kul'tura: kontent, kontseptsiyi, 
perspektyvy (ukrayins'ko-pol's'kyy dosvid) / kolektyvna monohrafiya: [Y. Los', S. Havrons'kyy, T. Lyl'o, M. Ulita ta in.]. L'viv : LNU imeni Ivana Franka, S. 280-294 [in Ukrainian].

23. Yashenkova O. V. (2010) Osnovy teoriyi movnoyi komunikatsiyi [Fundamentals of the theory of speech communication: textbook. way] : navch. posib. / O. V. Yashenkova. K : VTS «Akademiya». 312 s. [in Ukrainian].

24. Camille Passler Schuster, Michael J Copeland (1996) Cross-cultural communication: Issues and implications // International business negotiations, S. 131-152. [in English].

25. Camille Passler Schuster, Michael J Copeland (2008) Cultural theory in use: the intersection of structure, process and communication in business practice Journal of Public Affairs: An International Journal 8 (4), S. 261-280. [in English]. 